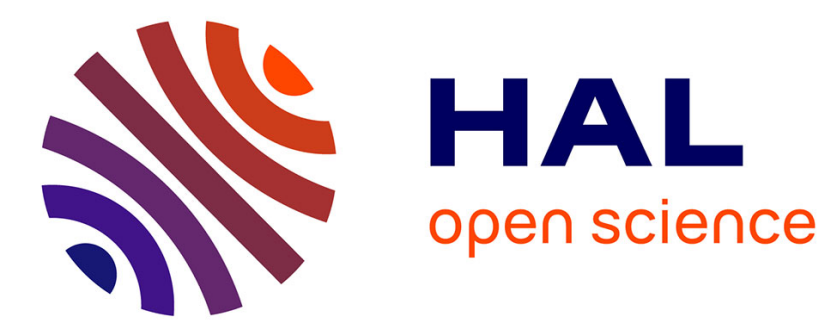

\title{
Combining farmers' decision rules and landscape stochastic regularities for landscape modelling
}

Noémie Schaller, El Ghali Lazrak, Philippe Martin, Jean-Francois Mari, Christine Aubry, Marc Benoît

\section{> To cite this version:}

Noémie Schaller, El Ghali Lazrak, Philippe Martin, Jean-Francois Mari, Christine Aubry, et al.. Combining farmers' decision rules and landscape stochastic regularities for landscape modelling. Landscape Ecology, 2012, 27 (3), pp.433-446. 10.1007/s10980-011-9691-2 . hal-00656407

\section{HAL Id: hal-00656407 https://hal.inria.fr/hal-00656407}

Submitted on 4 Jan 2012

HAL is a multi-disciplinary open access archive for the deposit and dissemination of scientific research documents, whether they are published or not. The documents may come from teaching and research institutions in France or abroad, or from public or private research centers.
L'archive ouverte pluridisciplinaire HAL, est destinée au dépôt et à la diffusion de documents scientifiques de niveau recherche, publiés ou non, émanant des établissements d'enseignement et de recherche français ou étrangers, des laboratoires publics ou privés. 


\section{Combining farmers' decision rules and landscape stochastic regularities for landscape modelling}

Noémie Schaller, El Ghali Lazrak, Philippe Martin, Jean-François Mari, Christine Aubry, Marc Benoît

N. Schaller (corresponding author); P. Martin; C. Aubry AgroParisTech INRA, UMR 1048 SAD-APT, Bâtiment EGER, BP 01, F-78850 ThivervalGrignon, France

email: noemie.schaller@agroparistech.fr

phone: +33 (0)1308155 95; fax: +33 (0)130815939

E.G. Lazrak; M. Benoît

INRA, UR 055 SAD ASTER, F-88500 Mirecourt, France

J.F. Mari

LORIA, UMR CNRS 7503 INRIA-Grand-Est, B.P. 239, F-54506 Vandœuvre-lès-Nancy, France The original publication is available at www.springerlink.com http://www.springerlink.com/content/mx6r7q7662307755/ 


\section{Abstract}

Landscape spatial organization (LSO) strongly impacts many environmental issues. Modelling agricultural landscapes and describing meaningful landscape patterns are thus regarded as keyissues for designing sustainable landscapes. Agricultural landscapes are mostly designed by farmers. Their decisions dealing with crop choices and crop allocation to land can be generic and result in landscape regularities, which determine LSO. This paper comes within the emerging discipline called "landscape agronomy", aiming at studying the organization of farming practices

at the landscape scale. We here aim at articulating the farm and the landscape scales for landscape modelling. To do so, we develop an original approach consisting in the combination of two methods used separately so far: the identification of explicit farmer decision rules through onfarm surveys methods and the identification of landscape stochastic regularities through datamining. We applied this approach to the Niort plain landscape in France. Results show that generic farmer decision rules dealing with sunflower or maize area and location within landscapes are consistent with spatiotemporal regularities identified at the landscape scale. It results in a segmentation of the landscape, based on both its spatial and temporal organization and partly explained by generic farmer decision rules. This consistency between results points out that the two modelling methods aid one another for land-use modelling at landscape scale and for understanding the driving forces of its spatial organization. Despite some remaining challenges, our study in landscape agronomy accounts for both spatial and temporal dimensions of crop allocation: it allows the drawing of new spatial patterns coherent with land-use dynamics at the landscape scale, which improves the links to the scale of ecological processes and therefore contributes to landscape ecology.

\section{Key words}


Land-use dynamic, on-farm survey, conceptual model, data mining, crop succession, crop allocation, spatiotemporal analysis, landscape agronomy, landscape patterns 


\section{Introduction}

Agriculture is the most important land use across Europe (Rounsevell et al 2003) and its impacts on the environment are no longer to be demonstrated (Donald et al 2001; Stoate et al 2001). Depending on market conditions, access to technology and public policies, subsequent intensification or abandonment can have contrasting effects from one region to another and even within regions (Stoate et al 2009). Considering the landscape scale of agroecosystems is thus necessary to address many ecological processes.

Landscape spatial organization (LSO) strongly impacts many environmental issues. Agricultural landscapes in Europe are composed of a crop mosaic and of semi-natural areas

10 (Burel and Baudry 2010). We focus here on the crop mosaic, directly influenced by agricultural practices and we define the LSO as the spatial structure and arrangement of the agricultural plots within the landscape. Several studies have shown that modifying the LSO can orientate environmental processes like biodiversity preservation (Benton et al 2003; Joannon et al 2008), soil erosion by water and tillage (van Oost et al 2000), erosive runoff (Joannon et al 2006), water

15 pollution (Benoît et al 1997; Beaujouan et al 2001) and gene fluxes (Le Bail et al 2010).

In order to understand the interactions between LSO and ecological processes, it is necessary to identify and describe meaningful landscape patterns (Turner 1990), both for scientists and planners. The identification and description of such landscape patterns could improve the understanding of environmental processes in relation with agricultural dynamics,

20 which may facilitate the exploration of the future and political decision making (Lazrak et al 2010a). Modelling agricultural landscapes is thus a key-step in exploring land-use dynamics and helping design sustainable and environmentally-friendly landscapes (Veldkamp and Lambin, 2001; Gaucherel and Houet, 2009). 
Agricultural landscapes are primarily designed by farmer practices (Benoît, 1990; Le Ber

25 et Benoît 1998; Thenail et al, 2009). Farmer decisions dealing with crop choices and crop allocation to land at farm scale impact LSO (Thenail and Baudry, 2004). As a consequence, there is a spatial mismatch between the landscape scale, where environmental processes occur and should be managed, and the farm scale, where landscape units are managed through farmer practices (Rindfuss et al 2004; Cumming et al 2006; Pelosi et al 2010). This mismatch calls for a

30 better articulation between the farm and the landscape scales.

As agronomists, we usually focus on farmer practices and soil-crops-climate interactions at the farm scale. Our research here focuses on the role of farmers in the landscape design process and is thus part of an emerging branch of agronomy called "landscape agronomy" (Benoît et al 2007). This discipline focuses on the landscape scale and aims at studying the organization of

35 farming practices on a small geographical scale (Mignolet et al., 2007). The scale generally ranges from $100 \mathrm{~km}^{2}$ to a few thousand $\mathrm{km}^{2}$ and is thus intermediate between the farm scale $(0.1$ to $10 \mathrm{~km}^{2}$ ) and coarser scales $\left(>100000 \mathrm{~km}^{2}\right)$. Landscape agronomy has recently developed due to the increased attention given to localised environmental problems resulting from farming activity (Benoît et al 2007). It combines concepts and methods from geographers and

40 agronomists: multi-scale modelling approaches for land-use changes (Veldkamp and Fresco 1996; De Koning et al 1999; Lambin et al 2003) and analytical methods to describe the underlying reasoning of regional agricultural systems organization. It relies mostly on the spatialization of farming system classifications (Landais 1998; Leisz et al 2005; Mignolet et al 2007).

Farmer decisions dealing with crop choices, crop successions and crop allocation to land have already been modelled at farm scale (Maxime et al 1995; Aubry et al, 1998a ; Navarrete and Le Bail, 2007; Mawois et al, 2011). Besides, some authors have shown that farmers organize their 
crops in the farming territory according to spatial constraints (Morlon and Benoît 1990; Morlon and Trouche 2005), especially on mixed crop-livestock farms (Brunschwig et al 2006; Marie et al 50 2009). It is now accepted that the way a farmer organizes his farming territory is related to his cropping plan and is both a time and a spatial process (Dury et al 2011).

Even if taken at the individual level, some decisions can be generic (i.e. shared by a set of farmers) and may result in landscape spatiotemporal regularities. Such regularities have already been stochastically modelled at the landscape scale (Lazrak et al 2010a). These authors consider

55 that land-uses are heterogeneously distributed among different polygons (agricultural plots) across landscapes and these land-uses display dynamic patterns as a result of crop successions and other driving forces of land-use changes. These patterns can be modelled both in their spatial and temporal dimensions using a Markovian framework (Le Ber et al 2006; Mignolet et al 2007; Castellazzi et al 2008; Lazrak et al 2010a) or stochastic decision trees (Sorel et al 2010). In short, there are methods for identifying (i) farmer decisions at farm scale and (ii) regularities in spatial and temporal landscape patterns at landscape scale, but very few studies aim at articulating the farm and the landscape scales by linking the two methods (Pocewicz et al 2008). Agent-based models have been widely used to simulate land-use changes as a result of human decisions, but these approaches do not account for technical factors: they rather focus on

65 the impact of economic factors (e.g. agricultural and development policies, land ownership) on farm structure or land cover changes (Freeman et al 2009; Happe et al 2009; Robinson and Brown 2009). Upscaling to the regional scale is even possible thanks to probabilistic approaches (Valbuena et al 2010), but disregarding the diversity of farmer practices. Following these authors, we now hypothesize that combining methods for identifying farmer logics and landscape

70 regularities could bridge the gap between crop patterns generated by farmers and agricultural landscape modelling. The aim of the paper is thus to model farmer decisions and landscape 
regularities, as well as the links between them, in order to improve the articulation of the farm and the landscape scales for regional land use modelling. To do so, we used a French case study, where researchers more widely aim at understanding (i) how farmers make their crop allocation

75 choices at farm scale and the associated determinants (ii) what landscape regularities can be identified at landscape scale in relation to farmer decisions, and (iii) how the landscape is finally designed and spatially organized over time. Once we have presented each of the two modelling methods, we will show how they mutually benefit one another before discussing advances, future challenges and perspectives for landscape modelling.

80

\section{Methods}

Study area

85 We applied our approach to the case of the Niort plain landscape in France. This area is located in the South of Deux-Sèvres in the Poitou-Charentes region $\left(46.2^{\circ} \mathrm{N}, 0.4^{\circ} \mathrm{W}\right)$. Its extent is about 350 $\mathrm{km}^{2}$ (Lazrak et al 2010a), the average plot area being about 4-5 ha ${ }^{1}$. This agricultural landscape comprises woods and villages (4\% of the total area) and is mainly composed of cereals, maize, sunflower, rapeseed and of a minority of grasslands (15\%). The number of mixed crop-livestock

90 farms (cattle and goats) has indeed been reduced in favour of arable farms. The Niort plain is a European Natura 2000 area where LSO particularly matters for biodiversity preservation and both water quality and quantity issues.

Methods at farm scale

${ }^{1}$ http://www.zaplainevaldesevre.fr/index.php 


\section{On-farm surveys and farmer decision rules}

In order to model farmer decisions, we combined farmer decision rules (Sebillotte and Soler 1990; Aubry et al 1998b; Merot et al 2008) and the conceptual modelling framework of the on-

100 farm resource use model (Aubry et al 1998a and 2006; Navarrete and Le Bail 2007). The model of on-farm resource use describes the content and the determinants of such decision rules. We thus built a generic conceptual framework to model farmer decisions through (i) decisional variables, (ii) determinants and (iii) decision rules.

(i) Decisional variables describe the content of the decision and give an answer to the question:

105 "what is the decision about?" For allocating crops to land at farm scale, decisional variables have been identified as: suitable cultivation area for each crop (all suitable plots for the considered species), crop area (total area of a considered crop on the farming territory), crop return time (acceptable time to replant the same crop on the same plot) and preceding-following crop pairs (acceptable temporal crop sequences) (Maxime et al 1995; Aubry et al 1998a; Navarrete and Le

110 Bail 2007).

(ii) Determinants are all elements influencing the decisional variables: they can be of different natures (quantitative or qualitative) and internal (e.g. farm resources) or external to the farm (e.g. market conditions, climate). For example, on-farm labour force and market prices can determine the crop areas.

115 (iii) Decision rules are the rules each farmer defines and follows, depending on the determinants, to make his choice for each decisional variable. For example, a rule could be "if the price of this crop is lower than [a threshold], then I will decrease this crop area". 
In this study, we applied this rule-based model to analyse decisions dealing with crop choices and crop allocation to land. The necessary data for such a model requires specific on120 farm surveys (Merot et al 2008). Between 2006 and 2010, we carried out 67 surveys in the Niort plain landscape. We sampled 67 farms out of the 185 farms having the whole farming territory inside the study area. The sample was built in order to account for the diversity in farming systems and not to be representative of all farms. All on-farm surveys aimed at understanding the global functioning of the farm. In addition, we distinguished four specific goals, which were

125 achieved through four successive sessions of on-farm surveys: 22 surveys in 2006 and 19 surveys in 2007 focused respectively on breeder and arable farmer strategies to cope with summer droughts and irrigation bans (Martin et al 2009; Havet et al 2010); 12 surveys in 2009 focused on farmer decisions dealing with crop spatial allocation and plot splitting (Schaller et al 2010); 14 surveys in 2010 focused on the evolution over time of farmers' annual cropping plans. The 67 on-

130 farm surveys were semi-structured to encourage farmers to specify the reasons for their choices and how these choices could evolve over time, especially regarding the way they allocated crops to land.

The on-farm understanding of such rotational principles and land allocation are now considered as the driving factors of landscape patterns (Thenail et al 2009). Such patterns can be

135 detectable by statistical methods (Castellazzi et al 2007) and data mining methods (Mignolet et al 2007; Lazrak et al 2010a).

Methods at landscape scale 
To identify landscape stochastic regularities, we used a data-base providing information about the land-use in the Niort plain. This data-base was built by the Chizé Centre for Biological Studies, based on biannual land-use surveys covering an extent of $350 \mathrm{~km}^{2}$ and going back to 1996

145 (Lazrak et al 2010a). The two surveys in April and June made it possible to account for both early-harvested and late-planted crops. Each year, surveyors distinguished 47 land-uses (42 agricultural, 3 urban and 2 forest land-uses) and updated the plot limits when necessary (Lazrak et al 2010a). The land-use surveys resulted in a GIS geodatabase in vector format.

\section{Theoretical background for modelling landscape regularities}

In order to model temporal and spatial landscape regularities, we used a stochastic data-mining approach based on a Markovian framework. Stochastic modelling for data mining is a convenient way of building statistical and probabilistic models for capturing the spatiotemporal data

155 variability that is not yet fully understood. This Markovian framework is based on two assumptions in spatial and temporal domains respectively: (i) the Markov random field (MRF) assumption assumes that the land-use of a given field depends only on the land-use of the neighbouring fields; (ii) the Markov chain assumption assumes that the land-use of a given field in a year depends only on the land-use of the recent previous years in the same field. We used

160 second order Hidden Markov Models (HMM2) to approximate the Markov assumptions, assuming that the distribution observations (land-uses) in an area at time $t$ - the cropping plan depend on the cropping plan observed at time $t-1$ or $t$-2. Hidden Markov Models (HMM) generalize Markov chains (Castellazzi et al 2008) through the presence of a supplementary hidden layer of states that models data structure and captures the variability of the observations.

165 HMMs have been successfully used in speech recognition (Jelinek 1976), image processing 
(Benmiloud and Pieczynski 1995), ecology (Le Ber et al 2006) and landscape agronomy (Lazrak et al 2010a).

An HMM2 is defined by 3 elements:

170 (i) A set $S=s_{1}, s_{2}, \ldots, s_{N}$ of $N$ states. The states are the outcomes of the variables $X_{t}$, where $t=1$, ..., $T$.

(ii) A transition matrix $A=\left(a_{i j k}\right)$ over $S^{3}$, where $a_{\mathrm{ijk}}$ is the a priori transition probability $P\left(X_{t}=s_{k} /\right.$ $X_{t-2}=s_{i}, X_{t-1}=s_{j}$ ) for the hidden Markov chain to be in state $s_{k}$ at index $t$ assuming it was in state $s_{\mathrm{j}}$ at index $t-1$ and $s_{\mathrm{i}}$ at index $t-2$. The Markov assumptions state that these a priori transition 175 probabilities are constant.

(iii) A set of $N$ distributions over a set of observations: $b_{i}($.$) is the distribution of the observations$ associated with state $s_{i}$. The observations may be of different types: single land-use of a plot, several land-uses - called $n$-uplet - corresponding to the plot occupations during $\mathrm{n}$ successive years, or corresponding to the occupations of the $\mathrm{n}$ neighbouring plots. These distributions may

180 be parametric: for example implemented in specific tables that store the observation probabilities, or represented by other HMMs that analyze an observation sequence at a whole and compute its probability. In this case, the HMM is called a hierarchical HMM. In our landscape clustering study based on land-use successions, we used a master HMM2 having 6 states, each of them being a 12 state HMM2. This latter analyzes the 12 year land-uses of a plot and computes the 185 time-sequence probability. The master HMM has an ergodic topology: all the states are interconnected. The states describe the homogeneous areas (called patches) in the landscape. The transition probabilities account for the neighbourhood relations between patches. The master HMM models the spatial structure whereas the state HMM models the temporal structure. Such a model is capable of clustering a landscape into 6 patches whose evolution in terms of land-use 
successions is represented by a 12 state HMM. A more extended presentation of HMM2s, together with their performances in several data mining studies in agronomy and ecology can be found in Le Ber et al (2006), Lazrak et al (2010a).

Two separate and complementary data-mining analyses were conducted. In the first one, the observations are the land-uses of a plot. The regularities are revealed by a hierarchical HMM2 195 through the segmentation of the landscape into homogeneous patches, each of them having its land-use evolution described by a temporal state HMM2. In the second one, the observations are n-uplets elaborated from the land-uses of the neighbourhood plots. The regularities are revealed through the evolution of land-use neighbourhoods over time represented by a simple linear 6 state HMM2 that processes the $n$-uplets.

Data-mining software for identifying landscape regularities

ArPentAgE ${ }^{2}$ (Analyse de Régularités dans les Paysages: Environnement, Territoires, Agronomie = Landscape Regularities Analysis: Environment, Territories and Agronomy) is a software based 205 on HMM2 for analyzing spatiotemporal data-bases (Lazrak et al 2010a). ARPENTAGE takes as input an array of discrete data in which the columns contain the annual land-uses and the rows are regularly spaced locations of the studied landscape. The data-mining process starts with the data preparation, which consists of three stages: (i) defining land-use categories to reduce the great number of land-use modalities, (ii) defining the elementary observation (single category vs. $n$ 210 uplet made of several land-use categories) and (iii) choosing the spatial resolution to sample the studied landscape (Lazrak et al 2010a) because ARPENTAGE runs on raster data.

\footnotetext{
${ }^{2}$ http://www.loria.fr/ jfmari/App/
} 
We simplified the 47 initial land-uses into 10 land-use categories as described by Lazrak et al (2010a), with the slight difference that winter barley has been assigned to the "Wheat" category and the "Grassland and Alfalfa" category has been divided into two categories:

215 "Grasslands" and "Alfalfa" (Table 1).

\#Table 1 approximately here\#

We sampled the landscape with regular spaced grids ranging from $10 \mathrm{~m} \times 10 \mathrm{~m}$ up to $640 \mathrm{~m}$ x 640m. Using each grid, we computed a feature: the number of different 12-year land-use successions. With a coarse resolution, small fields are omitted so that their land-use successions

220 are lost. On the other hand, with a fine resolution, the huge matrix of sampled points does not allow tractable computations. We chose the method described in Lazrak et al (2010a) to determine the grid resolution. A study of the variation of this feature as a function of the resolution showed that a $80 \mathrm{~m}$ grid resolution was a satisfying trade-off to avoid both long calculation times and the omission of small plot characteristics: only $6 \%$ of the 12 -year land-use 225 successions were lost.

Land-use evolution data mining: clustering the Niort plain landscape into homogeneous patches

230 To perform the first data-mining analysis, we modelled the time-spatial structure of the landscape by a 6 state hierarchical HMM2 whose master HMM2 models the spatial structure, whereas the land-use evolution is modelled by the 12 state linear HMM2s (Figure 1). The purpose of a linear HMM2 is to segment the study period in as many temporal segments as states (Mari and Le Ber 2006). In our case, each state was associated with one year. We located the land-use evolution by 235 partitioning the study area into 6 homogeneous classes of patches in terms of land-use evolution. 
This value was obtained from previous studies on the same data (Lazrak et al 2010a) and appeared to be a trade-off between heavy computations and useful clustering.

\section{Land-use neighbourhood data mining: analyzing the time evolution of neighbourhoods}

In this second data-mining analysis, we aimed at representing more precisely the evolution of sunflower and maize neighbourhoods over time, since these crops are in jeopardy in the region

245 due to their sensitivity to summer droughts. To do so, we explicitly considered their neighbourhood relationships in the studied landscape.

The elementary observation was a 5-uplet of land-uses, also called quintuplet. A $80 \mathrm{~m}$ resolution gave too many neighbourhoods (approximately 40000 different land-use quintuplets, more than the computer can process). We reduced this number by replacing land-use quintuplets

250 by land-use cliques. A clique is a 2-uplet made of the land-uses of 2 neighbouring plots, regardless to their directions (Lazrak et al 2010b). This replacement requires prior verification of the hypothesis that the land-use mosaic is isotropic (i.e. the direction does not hold any information). We studied the distribution of the 5-uplets occurring in the 12-year study period and calculated the marginal joint probability $\mathrm{P}(\mathrm{S}, \mathrm{N})$ in each direction (North, South, East, West),

255 where $\mathrm{S}$ and $\mathrm{N}$ are random variables of land-use categories respectively in a site and in its neighbour site. For the studied landscape, we found that $\mathrm{P}(\mathrm{S}, \mathrm{N})$ were equal whatever the direction of neighbourhoods, which confirms that land-use mosaic is isotropic and allows us to use the land-use cliques as elementary observations. 
In order to assess the co-location of two land-use categories ( $\mathrm{x}$ and $\mathrm{y}$ ), we used Pointwise

260 Mutual Information (PMI). PMI is usually used in text-mining (Novovičová et al 2004) to find pairs of co-located words. It is defined as follows:

$\operatorname{PMI}(\mathrm{x}, \mathrm{y})=\log (\mathrm{P}(\mathrm{N}=\mathrm{x}, \mathrm{S}=\mathrm{y}) / \mathrm{P}(\mathrm{N}=\mathrm{x}) * \mathrm{P}(\mathrm{S}=\mathrm{y}))$

PMI compares the probability of observing $\mathrm{x}$ and $\mathrm{y}$ : together (joint probability) and independently (chance). If there is an attraction between $\mathrm{x}$ and $\mathrm{y}$, the joint probability $\mathrm{P}(\mathrm{x}, \mathrm{y})$ is

265 larger than $\mathrm{P}(\mathrm{x}) * \mathrm{P}(\mathrm{y})$ and then $\mathrm{PMI}>0$ (Church and Hanks 1989). Inversely, if there is a repulsion between $\mathrm{x}$ and $\mathrm{y}, \mathrm{P}(\mathrm{x}, \mathrm{y})$ is lower than $\mathrm{P}(\mathrm{x}) * \mathrm{P}(\mathrm{y})$ and then $\mathrm{PMI}<0$. A zero value means that allocation to land of $\mathrm{x}$ is independent of the allocation of $\mathrm{y}$ since $\mathrm{P}(\mathrm{x}, \mathrm{y})=\mathrm{P}(\mathrm{x})^{*} \mathrm{P}(\mathrm{y})$. Through onfarm surveys, agronomists may seek the decision rules explaining the data-mined attraction or repulsion regularities between land-use categories.

We here calculated the PMI on the basis of the cliques, regardless of their orientation. We then analysed the evolution of the neighbouring relationships of sunflower and maize by clustering the study period with a linear HMM2 of 6 states. This linear HMM2 defines six disjoint periods. In order to draw a global overview on neighbouring land-use evolution, we chose the periods 1998-2000 and 2004-2006 corresponding to states 2 and 5 of the 6-state linear 275 HMM2.

By confronting the results of on-farm surveys about farmer decisions and the results of data-mining about landscape stochastic regularities, we now assess the coherence of the two approaches and how they can aid one another for landscape modelling.

\section{Results}


Farmer decision rules can be assessed at the landscape scale thanks to landscape stochastic regularities: example of sunflower

285 Through on-farm surveys from 2006 to 2010, we identified common farmer decision rules regarding sunflower. After 2005, farmers generally chose to decrease the total area dedicated to sunflower on their farming territory (39 out of 67; Table 2). This decision was explained by two factors. The first one was the frequent summer droughts occurring in the region and particularly affecting sunflower yields, since this crop is planted in spring and needs water during summer.

290 Farmers tended to replace sunflower by a less risky crop like rapeseed. The second factor was the European Common Agricultural Policy (CAP) reform of 2003 applied since 2006 in France. This factor specifically concerned mixed crop-livestock farms. Before the CAP reform, farmers got compensatory payments on the basis of the amount produced (product based subsidies): they had a specific amount of money for each cash crop, but no subsidy for grasslands. After the reform

295 and the decoupling, they got single payments only depending on the eligible farm area (land based subsidies) and regardless of their cropping plans and production (Bougherara and Latruffe 2010). As a consequence, before the reform, most breeders tended to grow rye-grass until May to cut it once for hay, but they planted sunflower just thereafter in order to get the annual subsidy. On the contrary, they now more frequently keep the planted rye-grass until fall to cut it several 300 times in the year and get the subsidy even without sunflower. The decision of decreasing the sunflower area implied another decision at farm scale: some farmers reduced the suitable crop area of sunflower on their farming territories and they concentrated it on the best places for sunflower. They stopped growing it close to the forests due to frequent damage of rabbits and crows in the vicinity of forests. In table 2 , we give the number of farmers having explicitly 305 enunciated this rule ( 9 out of 26 asked farmers). One should however note that, unlike the 9 
farmers having enunciatedthe rule, 10 farmers out of 26 did not have several patches of forests within a 500m-distance of the plots or did not grow sunflower on their farms, and were thus not concerned by this rule.

\#Table 2 approximately here\#

310 We sought landscape stochastic regularities involving sunflower in order to see if the farmer decision rules identified at farm scale were consistent with observed landscape dynamics. First, the sunflower frequency substantially fell in the late 2000's at the landscape scale: the frequency was approximately divided by a factor of 2 between 1996 and 2007 (Figure 2). Furthermore, figure 3(a) shows the evolution of the PMI between sunflower and other land-uses

315 over the period and at landscape scale. It suggests that sunflower was in a relation of spatial repulsion with forests and grasslands over the whole period, while it was in a relation of spatial attraction with rapeseed and wheat. Besides, sunflower became less frequently close to forests and maize over the studied period. This landscape spatiotemporal regularity is thus consistent with individual farmer decision rules identified by on-farm surveys, which could explain the 320 regularity at the landscape scale. \#Figures 2 and 3 approximately here\#

Farmer decision rules contribute to explaining landscape stochastic regularities: example of maize

325 In parallel with the first example, figure 3(b) shows the evolution between the beginning (19982000) and the end (2004-2006) of the period of the PMI between maize and other land-uses at landscape scale. It clearly suggests that maize was more frequently close to grasslands (stronger attraction) and less frequently close to wheat (weaker attraction). It also shows that maize and 
respectively forests, sunflower and especially rapeseed were increasingly repulsed over the

330 period.

We sought to identify generic farmer decision rules that would give explanatory elements to this time evolution of the neighbourhoods. Through on-farm surveys, we found that the maize area tended to decrease and to be mostly maintained in the vicinity of grasslands for several reasons. In fact, farmers had to adapt to a context of frequent summer droughts in the Niort plain

335 landscape, leading to temporary irrigation bans (Martin et al 2009). Maize (grain or silage) is only grown in deep humid soils, which are rather scarce in the Niort plain landscape $(17 \%$ of arable soils) and/or in irrigated plots. Consequently, the adaptation strategies to water shortage mainly depend on the access to deep soils and the farming system. A common decision rule regarding the suitable cultivation area is that farmers only grow maize in deep and humid soils when they have

340 no access to irrigation (40 out of 67 ; Table 2 ). They grow maize as a monoculture in the vicinity of grasslands traditionally well adapted to be located in deep and humid soils. 16 out of the 67 surveyed farmers were not concerned by the rule though, since they only grow corn in irrigated plots. Then, the crop allocation choices also depend on the farming system and the irrigation capacity, modulated by a risk of restriction. On arable farms, grain maize is not a priority crop

345 and too risky due to irrigation bans, so that arable farmers decide to decrease the maize area (Table 2). On mixed crop-livestock farms, maize is a priority crop for feeding herds. Maize is thus mainly maintained as silage when they have access to irrigation. At the same time, maize production becomes increasingly risky due to climate variability and irrigation restrictions, so that breeders tend to expand grasslands area to complement and secure fodder production (Table 2).

350 This approach results in maize being mainly maintained on mixed crop-livestock farms with significant grasslands area on farms. Finally, all these decisions appear to be generic and 
consistent with the fact that maize became more frequently close to grasslands over the period at landscape scale.

355 Links between time evolution of land-use neighbourhoods and clustering of the Niort plain landscape

After having commented the results concerning the analysis of the time evolution of landuse neighbourhoods, we now present the map resulting from the segmentation of the landscape

360 using a Markovian framework (Figure 4) and the possible consistency with previous results. This map consists of patches characterized by homogeneous evolution of land-use areas summarized in small associated graphs. The map thus gives the possibility to locate, inside the landscape, the places where a certain land-use area decreased or increased and to compare the patches regarding their land-use area evolutions over time. The map unit (a) refers to patches where maize is the

365 most frequent land-use. In these patches, grasslands seem to have increased since 2004 simultaneously to maize decrease. As a consequence, these patches may represent breeder practices, as described above. The map units (b) and (c) represent crop areas where maize has been partially replaced by grasslands. The map unit (d) refers to patches where grasslands are the most frequent land-use, which may correspond to areas with deep and humid soils. Despite a

370 global decreasing trend, maize appears to be more frequent in this grassland patch than in crop areas, which is consistent with the rule consisting in growing maize only in deep and humid soils. Map unit (e) represents patches were forests are the most important land-use and where sunflower is very scarce and decreasing over the period.

\#Figure 4 approximately here\# 


\section{Discussion}

A new framework for landscape modelling

380 We have here pointed out that the two modelling methods (farmer decision rules analysis and landscape stochastic regularities computation) aid one another for land-use modelling at the landscape scale and understanding the driving forces of its spatial organization. In line with Thenail et al. (2009) and Sorel et al. (2010), we argue that spatiotemporal crop allocation to field patterns is designed at the farm scale.

We managed to create a map of spatiotemporal regularities, partly explained by generic farmer decision rules (Figure 4). The combination of an ergodic HMM and a Markov chain made it possible to account for both spatial and temporal changes, despite the difficulties of handling both these dimensions (Verburg 2006). Following the work of Lazrak et al. (2010a), this map constitutes a partitioning of the landscape, based on both its spatial and temporal organization and maximizing the probability that the model fits the data. This drawing of new spatial patterns coherent with land-use dynamics at the landscape scale may improve the links to the scale of ecological processes (Pelosi et al 2010). We could in addition account for possible changes in crop proportions whereas simple transition matrices in Markov chains (Castellazzi et al 2008) induce stationary crop proportions when used to simulate crop successions.

Moreover, in contrast to a time-invariance of the socioeconomic context and of the driving factors of landscape changes (Sorel et al 2010), an originality of our approach relies on accounting for a changing context. The modification of socioeconomic and climatic driving factors induced in our case changes in crop proportions over the studied period. In the Niort plain region, the EU Common Agricultural Policy reform contributed to decreasing the total sunflower 
400 area, while the frequent drought risk contributed to reducing the maize area. These crop proportion changes resulted in changes in the landscape patterns, which can in turn impact environmental issues. Hence, our approach seems to be useful for landscape modelling and thus for a better knowledge of the interactions between ecological processes and landscape dynamics.

405 Remaining challenges

One limit of our approach is that not all farmer decisions are generic enough to be assessed at landscape scale. For example, through on-farm surveys, we identified two different management strategies for alfalfa. On arable farms, a common rule was to implant alfalfa all at the same time

410 in order to simplify the cropping system and only in marginal areas. It was also a mean for farmers to get specific subsidies within the framework of the CAP Territorial Agroenvironmental Measures implemented in France. On the contrary, on mixed crop-livestock farms, a common rule was to grow alfalfa of different ages ( 1 to 5 years). The gradual implantation aims at securing the fodder production considering that alfalfa yields depend on the age of the implanted alfalfa.

415 And yet, it was not possible to identify a spatiotemporal regularity about alfalfa. The fact that alfalfa concerns a marginal area $(<4 \%)$ compared to commercial crops can explain the difficulty in identifying landscape regularity and assessing the associated rule at landscape scale. Sorel et al (2010) also noted that marginal crops (the ones with small proportions of the landscape area) were the least well predicted concerning crop spatiotemporal allocation compared to major crops.

420 This observation confirms that stochastic modelling, either Markov models or stochastic decision trees, is difficult to carry out for marginal areas. Nevertheless, even if not all generic, we think that it is still important to identify these decisions because they give the possibility of identifying innovative and potential future farmer adaptations to a changing context. 
Moreover, as mentioned by Thenail and Baudry (2004), many decisions for

425 spatiotemporal crop allocation to landscape patterns are specific to certain farm types (e.g. arable vs. mixed crop-livestock farms). Given that the different farm types can be spread over discontinuous landscape units within the landscape, it is difficult to assess specific rules at the landscape scale. This is again consistent with the results of Sorel et al (2010): they appear to get less success in predicting spatiotemporal crop allocation when using generic Markov models than

430 when using farm type specific ones. In our approach, we did not identify stochastic regularities at the level of a discontinuous landscape composed by only a certain farm type: our interest was to link the farm and the landscape scales when farmer rules are generic enough to impact landscape patterns. One must however notice that the choice of considering continuous or discontinuous landscapes is of variable interest depending on the ecological process studied and the objective to 435 be achieved (Pelosi et al 2010).

A second limit of our approach is due to the difficulty in determining the part of each rule explaining a regularity when several farmer decision rules are possible. For example, we identified a strong regularity of neighbourhood between grasslands and built-up areas (not shown). Two possible farmer rules could explain this regularity. The first one is that most farmers

440 allocate permanent grass or set-asides instead of commercial crops next to houses in order to avoid agrochemical spraying in small plots close to citizens' houses. The second rule is that most dairy breeders put grasslands just next to the milking room so that dairy cows can graze in the vicinity of the dairy barn, which is in accordance with several authors (Benoit 1990; Marie et al 2009). Our difficulty is to determine the part of each rule in explaining the regularity of the 445 neighbourhood between grasslands and built-up areas, which is also related to the scarcity of available data: there is indeed no data-base about buildings in rural landscapes with a distinction between urban and agricultural buildings (and among them, with the specific use of each 
building). To overcome the difficulty of determining the explaining part of different rules, one interesting perspective of our work could be the complementary use of landscape simulation

450 software. We could generate landscape patterns according to different farmer rules and compare them to random landscapes vs. real landscapes.

Conclusion: contribution of landscape agronomy to landscape ecology

455 As a conclusion, the two modelling methods of farmer decisions and landscape regularities have been respectively used for a long time now. Our paper suggests that a new approach consisting in a combination of the two methods helps in articulating the farm and the landscape scales for landuse modelling and improving our understanding of land-use processes. The originalities rely on (i) the combination of two methods used separately so far and (ii) the accounting for both the 460 spatial and the temporal dimensions of crop allocation to landscape patterns in a changing context. Thanks to more on-farm surveys and to remote sensing improvements and developing spatial land-use data-bases (e.g. CAP declarations in Europe) for data-mining, such an approach could be applied in the future in other landscapes for upscaling.

As landscape agronomists, we consider that the crop mosaic inside agricultural landscapes 465 is organized by farmers. On the other hand, landscape ecologists view the landscape as a randomlike phenomenon influenced by natural factors (Burel and Baudry 2010). Our study therefore seeks to contribute to landscape ecology through a deeper insight into the relationships between landscape spatial organization, its driving forces and its impacts on ecological processes.

\section{Acknowledgements}


We thank the CEBC for the land-use data-base. We are also very grateful to Benoit Lelaure, Gaëdig Méola and Camille Bernard, who carried out the farmer surveys in 2006, 2007 and 2010. The PhD of N. Schaller was funded by the Ile-de-France region through the DIM ASTREA and the PhD of E.G. Lazrak was funded by the Lorraine Region and the ANR BioDivAgriM project. 475 We would like to sincerely thank Donald White for improving the English, Aude Barbottin and the three anonymous reviewers for their fruitful comments. 


\section{Tables}

Table 1: Land-use categories used for data-mining analysis (time period: 1996-2007)

\begin{tabular}{|c|c|c|c|}
\hline LAND-USE CATEGORY & LAND-USE & FREQUENCY & CUMUL. FREQUENCY \\
\hline Wheat (W) & $\begin{array}{l}\text { wheat, bearded wheat, winter barley, } \\
\text { cereal }^{(*)}\end{array}$ & 0.372 & 0.372 \\
\hline Sunflower (S) & sunflower, ryegrass followed by sunflower & 0.139 & 0.511 \\
\hline Rapeseed (R) & rapeseed & 0.124 & 0.635 \\
\hline Urban (U) & built area, peri-village, road & 0.095 & 0.730 \\
\hline Maize (M) & maize, rye grass followed by maize & 0.076 & 0.806 \\
\hline Grasslands (G) & $\begin{array}{l}\text { permanent grassland, grassland first year, } \\
\text { temporary grassland ( } 2-3 \text { years), grassland } \\
\text { of unknown age }\end{array}$ & 0.055 & 0.861 \\
\hline Forest and wasteland (F) & forest or hedge, wasteland (uncultivated) & 0.035 & 0.896 \\
\hline Alfalfa (A) & $\begin{array}{l}\text { alfalfa } 1^{\text {st }} \text { year, alfalfa } 2^{\text {nd }} \text { year, alfalfa } 3^{\text {rd }} \\
\text { year, alfalfa more than } 3 \text { years }\end{array}$ & 0.026 & 0.922 \\
\hline Ryegrass (Y) & ryegrass, ryegrass followed by ryegrass & 0.024 & 0.946 \\
\hline $\operatorname{Pea}(\mathrm{P})$ & pea & 0.022 & 0.968 \\
\hline Others $(\mathrm{O})$ & $\begin{array}{l}\text { spring barley, grape vine, spontaneous } \\
\text { fallow in June, foxtail millet, flax, oat, } \\
\text { clover, field bean, rye grass followed by } \\
\text { tillage, rye grass followed by unknown, } \\
\text { spontaneous fallow followed by tillage, } \\
\text { rye, cereal-legume mixture, spring crop, } \\
\text { mustard, garden/market gardening, } \\
\text { sorghum/millet, sorghum, millet, tillage, } \\
\text { tobacco, other crop }\end{array}$ & 0.032 & 1.000 \\
\hline
\end{tabular}


Table 2: Farmer decision rules regarding sunflower and maize allocation to land (identified through on-farm surveys)

\begin{tabular}{|c|c|c|c|c|c|c|c|}
\hline \multirow{2}{*}{$\begin{array}{c}\text { Decisional } \\
\text { variable }\end{array}$} & \multirow[t]{2}{*}{ Determinants } & \multirow[t]{2}{*}{ Decision rule } & \multicolumn{5}{|c|}{ Number of farmers applying the rule } \\
\hline & & & 2006 & 2007 & 2009 & 2010 & Total \\
\hline $\begin{array}{l}\text { Crop area for } \\
\text { sunflower }\end{array}$ & $\begin{array}{l}\text { Climatic risk } \\
\text { affecting yields; } \\
\text { CAP reform and } \\
\text { decoupling }\end{array}$ & $\begin{array}{l}\text { Reduce the } \\
\text { sunflower area }\end{array}$ & $12(/ 22)$ & $9(/ 19)$ & $7(/ 12)$ & $11(/ 14)$ & $39(/ 67)$ \\
\hline $\begin{array}{l}\text { Suitable } \\
\text { cultivation area } \\
\text { for sunflower }\end{array}$ & $\begin{array}{l}\text { Forests in the } \\
\text { neighbourhood } \\
\text { and associated } \\
\text { crop damage }\end{array}$ & $\begin{array}{l}\text { Plots close to } \\
\text { forests }(<500 \mathrm{~m}) \\
\text { not suitable for } \\
\text { sunflower }\end{array}$ & - & - & $3(/ 12)$ & $6(/ 14)$ & $9(/ 26)$ \\
\hline $\begin{array}{l}\text { Suitable } \\
\text { cultivation area } \\
\text { for maize } \\
\text { without } \\
\text { irrigation }\end{array}$ & $\begin{array}{l}\text { Type of soil } \\
\text { (depth and } \\
\text { humidity of soil) }\end{array}$ & $\begin{array}{l}\text { Only plots with } \\
\text { deep and humid } \\
\text { soils suitable for } \\
\text { maize without } \\
\text { irrigation }\end{array}$ & $9(/ 22)$ & $10(/ 19)$ & $9(/ 12)$ & $12(/ 14)$ & $40(/ 67)$ \\
\hline $\begin{array}{l}\text { Crop area for } \\
\text { maize on arable } \\
\text { farms }\end{array}$ & $\begin{array}{l}\text { Climatic risk } \\
\text { affecting yield; } \\
\text { only cash crop } \\
\text { function (sold) }\end{array}$ & $\begin{array}{l}\text { Reduce the } \\
\text { maize area on } \\
\text { arable farms }\end{array}$ & $5(/ 5)$ & $8(/ 10)$ & $3(/ 5)$ & $3(/ 6)$ & $19(/ 26)$ \\
\hline $\begin{array}{l}\text { Crop area for } \\
\text { maize on mixed } \\
\text { crop livestock } \\
\text { farms }\end{array}$ & $\begin{array}{l}\text { Maize is used to } \\
\text { feed herds }\end{array}$ & $\begin{array}{l}\text { Maintain maize } \\
\text { production on } \\
\text { mixed crop } \\
\text { livestock farms }\end{array}$ & $16(/ 17)$ & $8(/ 9)$ & $5(/ 7)$ & $6(/ 8)$ & $35(/ 41)$ \\
\hline $\begin{array}{l}\text { Crop area for } \\
\text { grasslands on } \\
\text { mixed crop } \\
\text { livestock farms }\end{array}$ & $\begin{array}{l}\text { Climatic risk } \\
\text { affecting maize } \\
\text { yields: need to } \\
\text { secure fodder } \\
\text { production }\end{array}$ & $\begin{array}{l}\text { Increase the } \\
\text { grasslands area } \\
\text { on mixed crop } \\
\text { livestock farms }\end{array}$ & $16(/ 17)$ & $9(/ 9)$ & $5(/ 7)$ & $5(/ 8)$ & $35(/ 41)$ \\
\hline
\end{tabular}


Figure 1: Example of hierarchical HMM2. Each spatial state a, b, c, d of the master HMM2 (ergodic model) is a temporal HMM2 (linear model) the states of which are 1, 2, 3. In our study, the ergodic model has 6 states, each of them being associated to a spatial area (patch), whereas the linear HMM2 have 12 states, each of them being associated to one year.

Figure 2: Frequency evolution of sunflower at the landscape scale over the study period

Figure 3: PMI between sunflower and other land-uses (a) and between maize and other land-uses (b). For each land-use, two confidence intervals show the evolution of the neighbourhood starting 495 in 1998-2000 (1) and ending in 2004-2005 (2). When the confidence intervals overlap themselves, only their union is shown. The interval shift shows the spatial attraction or repulsion process. The confidence intervals are computed using a $40 \mathrm{~m}$ resolution and a $5 \%$ risk. See Table 1 for land-use category details.

500 Figure 4: Segmentation of the Niort Plain landscape in patches characterized by homogeneous evolution of land-use areas over the studied period. White areas are unclassified because there was insufficiently surveyed land-use over the 1996-2007 period. The location of the Niort Plain in France is depicted in the upper left-hand box. The map legend (evolution of land-use areas in each patch) is illustrated in small graphs in the frame. There are 6 map units: (a) to (f). Each map

505 unit is described by 2 diagrams: (i) a left-hand diagram showing the evolution of all land-use categories in patches belonging to the considered map unit and (ii) a right-hand diagram showing a zoom on interesting land-use categories. The map unit (a) refers to patches where maize is the most frequent land-use. The map units (b) and (c) represent crop areas where maize has been 
partially replaced by grasslands. The map unit (d) refers to patches where grasslands are the most

510 frequent land-use. Map unit (e) represents patches were forests are the most important land-use. Map unit (f) represents urban areas. 
Figures

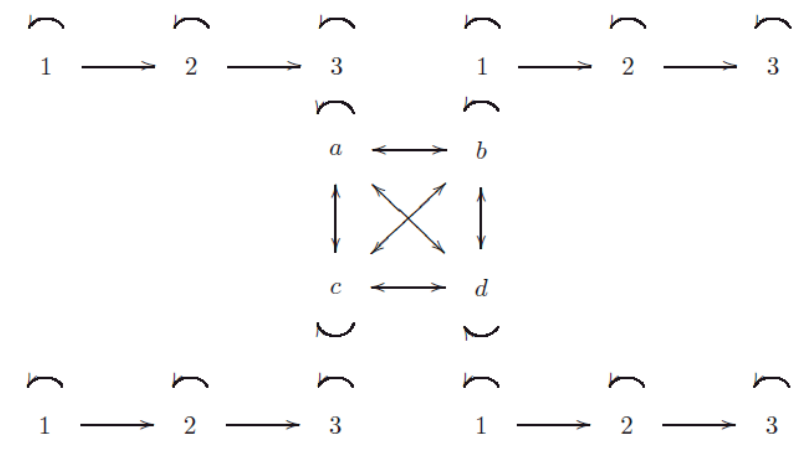

$515 \quad$ Figure 1 


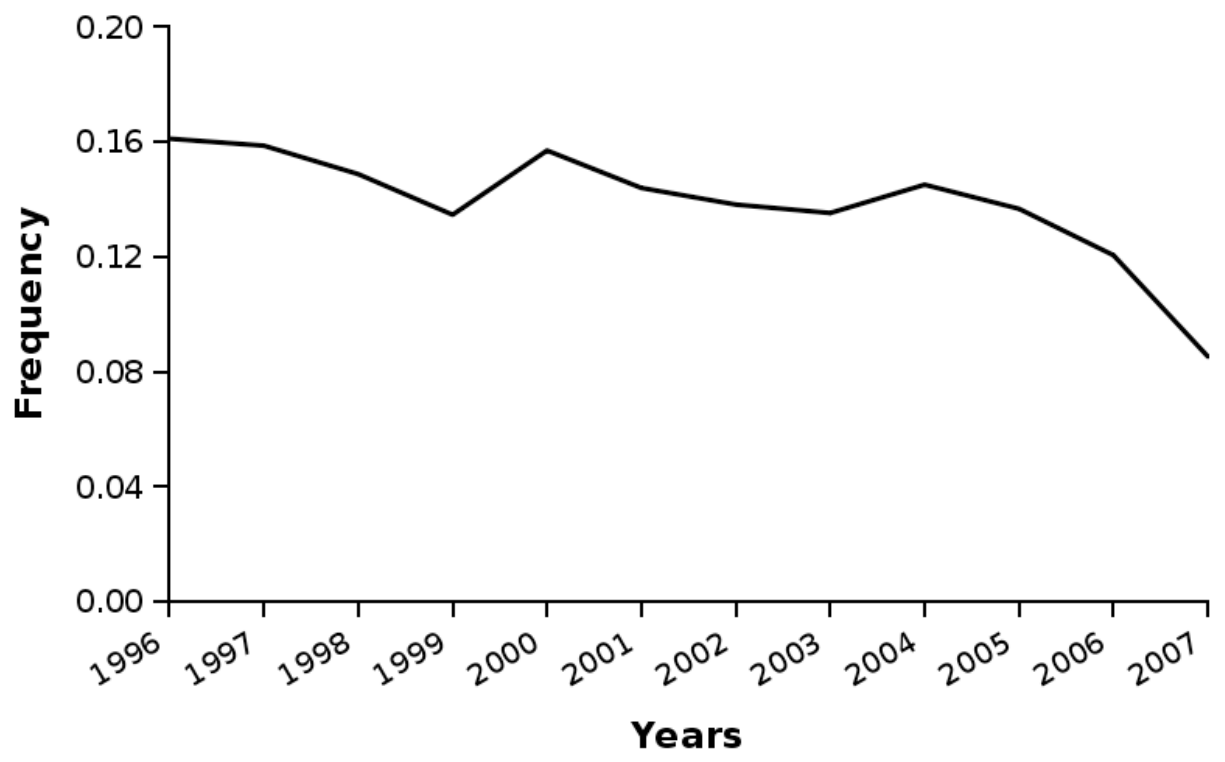

Figure 2 

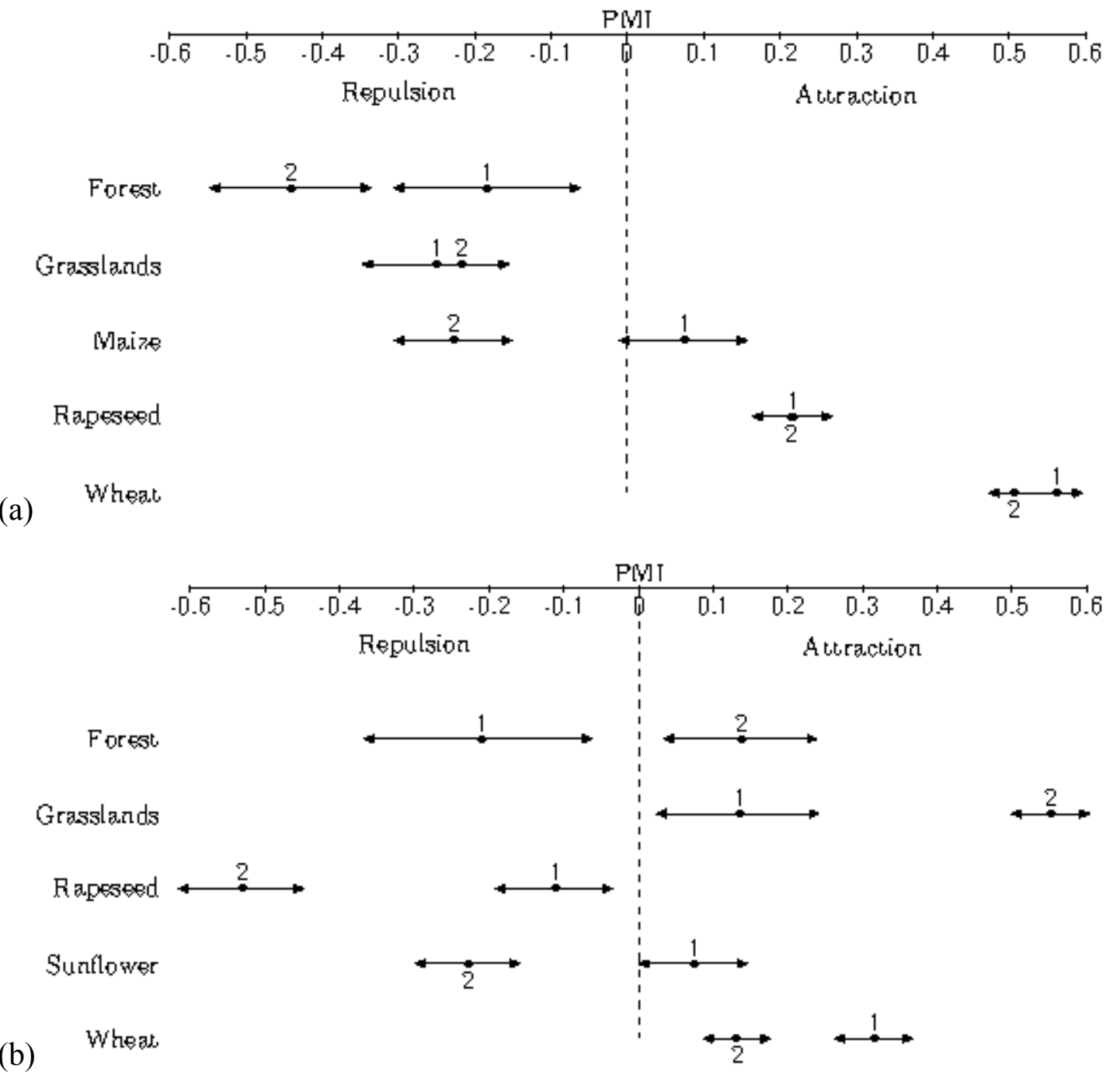

Figure 3 


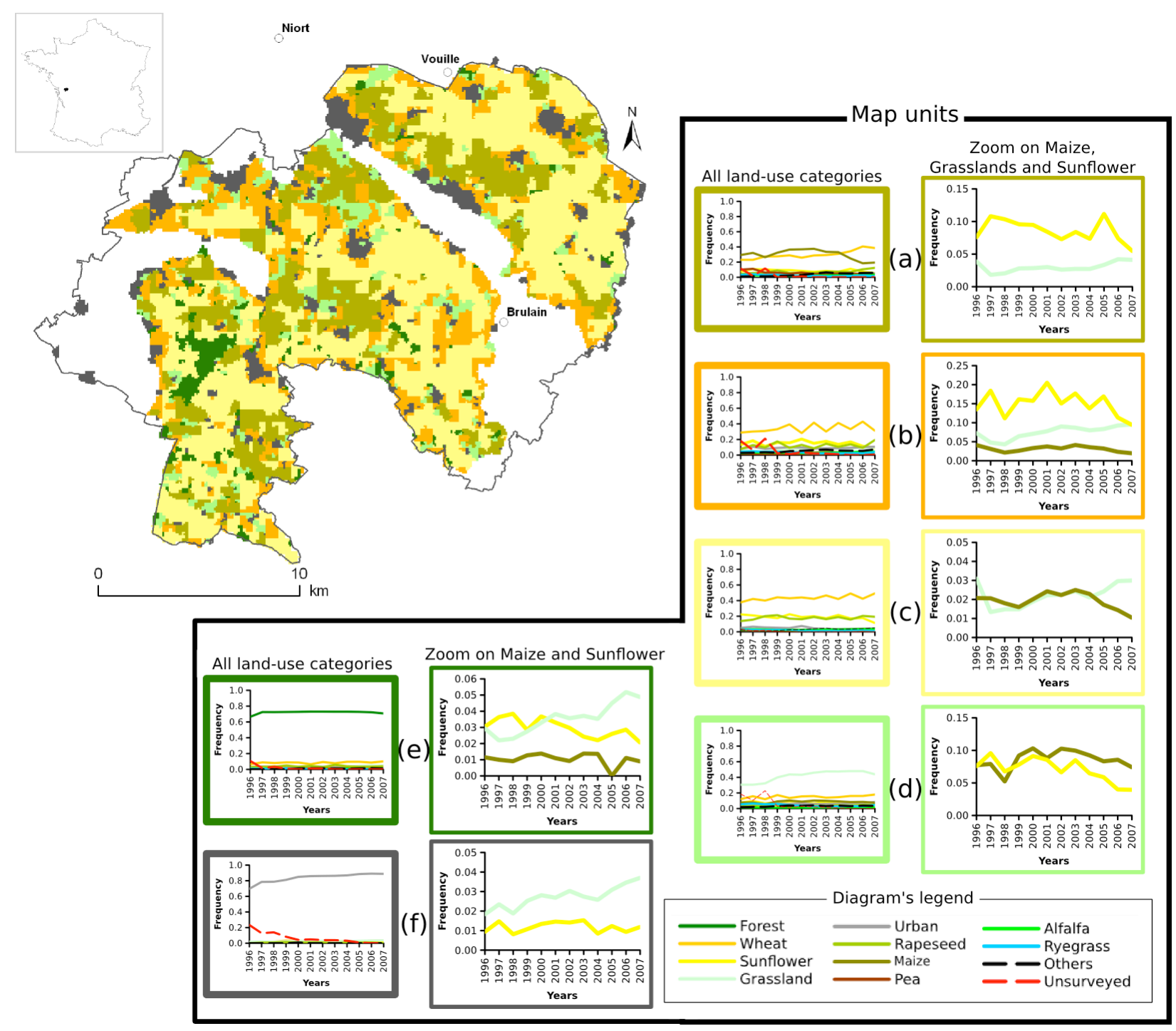

Figure 4 


\section{References}

525 Aubry C, Biarnes A, Maxime F, Papy F (1998a) Modélisation de l'organisation technique de la production dans l'exploitation agricole : la constitution de système de culture. Etud Rech Syst Agraires Dév 31: 25-43

Aubry C, Papy F, Capillon A (1998b) Modelling decision-making processes for annual crop management. Agric Syst 56(1): 45-65

530 Aubry C, Paillat J-M, Guerrin F (2006) A conceptual model of animal wastes management in the Reunion Island. Agric Syst 88: 294-315

Baker WL (1989) A review of models in landscape change. Landscape Ecology 2(2): 111-133.

Beaujouan V, Durand P, Ruiz L (2001) Modelling the effect of the spatial distribution of agricultural practices on nitrogen fluxes in rural catchments. Ecol Model 137: 93-105

535 Benmiloud B, Pieczynski W (1995) Estimation des paramètres dans les chaînes de Markov cachés et segmentation d'images. Traitement du signal, 12(5):433 - 454 .

Benoît M (1990) La gestion territoriale de l'activité agricole dans un village lorrain. Mappemonde 4: $15-17$

Benoît M, Deffontaines JP, Gras F, Bienaimé E, Riela-Cosserat R (1997) Agriculture et qualité de l'eau. Une approche interdisciplinaire de la pollution par les nitrates d'un bassin d'alimentation. Cah Agri 6: 97-105

Benoît M, Mignolet C, Hermann S, Rizzo D, Moonen C, Barberi P, Galli M, Bonari E, Silvestri N, Thenail C, Lardon S, Rapey H, Marraccini E, Le Ber F, Meynard JM (2007) Landscape as designed by farming systems: a challenge for landscape agronomists in Europe. In:

545 Farming Systems design 2007, methodologies for integrated analysis of farm production systems, Catania: 137-138 
Benton TG, Vickery JA, Wilson JD (2003) Farmland biodiversity: is habitat heterogeneity the key? TRENDS Ecol and Evol 18(4): 182-188

Bougherara D, Latruffe L (2010) Potential impact of the EU 2003 CAP reform on land idling decisions of French landowners: results from a survey of intentions. Land Use Pol 27(4): $1153-1159$

Burel F, Baudry J (2010). Landscape and resilience. In: Proceedings of 'Agro2010 the XIth ESA Congress', Montpellier, France: 143-144

Brunschwig G, Josien E, Bernhard C (2006) Contraintes géographiques et modes d'utilisation des parcelles en élevage bovin laitier et allaitant. Fourrages 185: 83-95

Castellazzi MS, Perry JN, Colbach N, Monod H, Adamczyk K, Viaud V, Conrad KF (2007) New measures and tests of temporal and spatial pattern of crops in agricultural landscapes. Agric Ecosyst Environ 118(1-4): 339-349

Castellazzi MS, Wood GA, Burgess PJ, Morris J, Conrad KF, Perry JN (2008) A systematic representation of crop rotations. Agric Syst 97(1-2): 26-33

Church KW, Hanks, P (1990) Word association norms, mutual information, and lexicography. Computational linguistics 16(1): 22-29

Cumming G, Cumming DHM, Redman CL (2006) Scale mismatches in social-ecological systems: causes, consequences, and solutions. Ecology and Society 11(1): 14

565 de Koning GHJ., Verburg PH, Veldkamp A, Fresco LO (1999) Multi-scale modelling of land use change dynamics in Ecuador. Agric Syst 61: 77-93

Donald P, Green RE, Heath MF (2001) Agricultural intensification and the collapse of Europe's farmland bird populations. Proc Roy Soc London 268: 25-29

Dury J, Schaller N, Garcia F, Reynaud A, Bergez JE (2011) Models to support cropping plan and 570 crop rotation decisions. A review. Agron Sust Dev Accepted 
Freeman T, Nolan J, Schoney R (2009) An agent-based simulation model of structural change in Canadian Prairie agriculture, 1960-2000. Can J of Agric Econ 57: 537-554

Gaucherel C, Houet T (2009) Preface to the selected papers on spatially explicit landscape modelling: current practices and challenges. Ecol Model 220: 3477-3480

575 Happe K, Schnicke H, Sahrbacher C, Kellermann K (2009) Will they stay or will they go? Simulating the dynamics of single-holder farms in a dualistic farm structure in Slovakia. Can J of Agric Econ 57: 497-511

Havet A, Martin P, Laurent M, Lelaure B (2010) Adaptation des exploitations laitières aux incertitudes climatiques et aux nouvelles réglementations. Le cas des productions bovines et caprines en Plaine de Niort. Fourrages 202: 145-151

Jelinek F (1976) Continuous Speech Recognition by Statistical Methods. Proc. IEEE, 64: 532556

Joannon A, Bro E, Thenail C, Baudry J (2008) Crop patterns and habitat preferences of the grey partridge farmalnd bird. Agron Sustain Dev 28: 379-387

585 Joannon A, Souchère V, Martin P, Papy F (2006) Reducing runoff by managing crop location at the catchment level, considering agronomic constraints at farm level. Land Deg Develop 17(5): 467-478

Lambin EF, Geist HJ, Lepers E (2003) Dynamics of land-use and land-cover change in tropical regions. Annu Rev Environ Resour 28: 205-241

590 Landais E (1998) Modelling farm diversity. New approaches to typology building in France. Agric Syst 58(4): 505-527

Lazrak EG, Mari JF, Benoît M (2010a) Landscape regularity modelling for environmental challenges in agriculture. Landscape Ecol 25: 169-183 
Lazrak EG, Benoît M, Mari JF (2010b) Time-Space Dependencies in land-use successions at the scale of an agricultural landscape. In: International Conference on Integrative Landscape Modelling - LandMod 2010, 8p. Available on Symposcience.

Le Bail M, Lecroart B, Gauffreteau A, Angevin F, Messean A (2010) Effect of the structural variables of landscapes on the risks of spatial dissemination between GM and non-GM maize. Eur J of Agr 33: 12-23

600 Le Ber F, Benoît M (1998). Modelling the spatial organization of land use in a farming territory. Example of a village in the Plateau Lorrain. Agronomie 18(2): 103-115

Le Ber F, Benoît M, Schott C, Mari JF, Mignolet C (2006) Studying crop sequences with CarrotAge, a HMM-based data mining software. Ecol Model 191(1): 170-185

Leisz SJ, Thu Ha NT, Bich Yen NT, Thanh Lam N, Duc Vien T (2005) Developing a methodology for identifying, mapping and potentially monitoring the distribution of general farming system types in Vietnam's northern mountain region. Agric Syst 85: 340-363

Mari J-F, Le Ber F (2006) Temporal and spatial data mining with second-order hidden markov models. Soft Comput 10: 406-414

Marie M, Bensaid A, Delahaye D (2009) Le rôle de la distance dans l'organisation des pratiques et des paysages agricoles : l'exemple du fonctionnement des exploitations laitières dans l'arc atlantique. Cybergeo: Eur J of Geography. Cartographie, Imagerie, SIG, article 460. URL : http://cybergeo.revues.org/index22366.html

Martin P, Schaller N, Havet A (2009) Diversity of farmers' adaptations to a new context of irrigation restrictions: consequences on grassland area development. In: Proceedings of the symposium Farming System Design, Monterey, CA: 249-250

Maxime F, Mollet JM, Papy F (1995) Aide au raisonnement de l'assolement en grande culture. Cah Agri 4: 351-362 
Mawois M, Aubry A, Le Bail M (2011) Can farmers extend their cultivation areas in urban agriculture? A contribution from agronomic analysis of market gardening systems around Mahajanga (Madagascar). Land Use Pol 28(2): 434-445

Merot A, Bergez JE, Capillon A, Wery J (2008) Analysing farming practices to develop a numerical, operational model of farmers' decision-making processes: An irrigated hay cropping system in France. Agric Syst 98(2): 108-118

Mignolet C, Schott C, Benoît M (2007) Spatial dynamics of farming practices in the Seine basin: Methods for agronomic approaches on a regional scale. Sci Total Environ 375: 13-32

Morlon P, Benoît M (1990) Étude méthodologique d'un parcellaire d'exploitation agricole en tant que système. Agronomie 6: 499-508

Morlon P, Trouche G (2005) Nouveaux enjeux de la logistique dans les exploitations de grande culture. L'organisation spatiale des assolements : exemple et questions. Cah Agri 14(3):

$630 \quad 305-311$

Navarrete M, Le Bail M (2007) SALADPLAN: a model of the decision-making process in lettuce and endive cropping. Agron Sust Dev 27(3): 209-221

Novovičová J, Malik A, Pudil P (2004). Feature selection using improved mutual information for text classification. In Fred A, Caelli T, Duin RPW, Campilho A, Ridder D (Eds.), Structural, Syntactic, and Statistical Pattern Recognition, Volume 3138 of Lecture Notes in Computer Science, 1010-1017. Springer Berlin, Heidelberg.

Pelosi C, Goulard M, Balent G (2010) The spatial scale mismatch between ecological processes and agricultural management: do difficulties come from underlying theoretical frameworks? Agric Ecosyst Environ 139: 455-462 
640 Pocewicz A, Nielsen-Pincus M, Goldberg CS, Johnson MH, Morgan P, Force JE, Waits LP, Vierling L (2008) Predicting land use change: comparison of models based on landowner surveys and historical land cover trends. Landscape Ecol 23: 195-210

Rindfuss RR, Walsch SJ, Turner II BL, Fox J., Mishra V (2004) Developing a science of land change: challenges and methodological issues. PNAS 101(39): 13976-13981

645 Robinson DT, Brown DG (2009) Evaluating the effects of land-use development policies on exurban forest cover: an integrated agent-based GIS approach. Int J of Geog Inform Sci 23(9): $1211-1232$

Rounsevell MDA, Annetts JE, Audsley E, Mayr T, Reginster I (2003) Modelling the spatial distribution of agricultural land use at the regional scale. Agric Ecosyst Environ 95(2-3): $465-479$

Schaller N, Aubry C, Martin P (2010) Modelling farmers' decisions of splitting agricultural plots at different time scales: a contribution for modelling landscape spatial configuration. In: Proceedings of 'Agro2010 the XIth ESA Congress', Montpellier, France: 879-880

Sebillotte M, Soler LG (1990) Les processus de décision des agriculteurs : acquis et questions vives. Modélisation systémique et systèmes agraires. J Brossier, Vissac B, Lemoigne JL, INRA Paris: 93-102

Sorel L, Viaud V, Durand P, Walter C (2010) Modeling spatio-temporal crop allocation patterns by a stochastic decision tree method, considering agronomic driving factors. Agric Syst 103: $647-655$

660 Stoate C, Baldi A, Beja P, Boatman ND, Herzon I, van Doorn A, de Snoo GR, Rakosy L, Ramwell C (2009) Ecological impacts of early 21st century agricultural change in Europe a review. J Environ Manag 91: 22-46 
Stoate C, Boatman ND, Borralho RJ, Rio Carvalho C, de Snoo GR, Eden P (2001) Ecological impacts of arable intensification in Europe. J Environ Manag 63(4): 337-365

665 Thenail C, Baudry J (2004) Variation of farm spatial land use pattern according to the structure of hedgerow network (bocage) landscape: a case study in Northern Brittany. Agric Ecosyst Environ 101: 53-72

Thenail C, Joannon A, Capitaine M, Souchère V, Mignolet C, Schermann N, Di Pietro F, Pons Y, Gaucherel C, Viaud V, Baudry J (2009) The contribution of crop-rotation organization in 670 farms to crop-mosaic patterning at local landscape scales. Agric Ecosyst Environ 131: 207219

Turner M. (1990) Spatial and temporal analysis of landscape pattern. Landscape Ecol 4: 21-30 Valbuena D, Verburg PH, Bregt AK, Ligtenberg A (2010) An agent-based approach to model land-use change at a regional scale. Landscape Ecol 25: 185-199

675 van Oost K, Govers G, Desmet P (2000) Evaluating the effects of changes in landscape structure on soil erosion by water and tillage. Landscape Ecol 15: 577-589

Veldkamp A, Fresco LO (1996) CLUE-CR: an integrated multi-scale model to simulate land use change scenarios in Costa Rica. Ecol Model 91: 231-248

Veldkamp A, Lambin EG (2001) Predicting land-use change: editorial. Agric Ecosyst Environ 680 85: $1-6$

Verburg PH (2006) Simulating feedbacks in land use and land cover change models. Landscape Ecol 21: 1171-1183 